\title{
A taxonomic review of Korean Leontopodium R. Br. ex Cassini (Asteraceae)
}

\author{
Dong-Hyuk Lee ${ }^{1,2}$, Jong-Su Park ${ }^{1}$, and Byoung-Hee Choi ${ }^{1 *}$ \\ ${ }^{1}$ Department of Biological Sciences, Inha University, 100, Inha-ro, Nam-gu, Incheon, Korea \\ ${ }^{2}$ Division of Forest Biodiversity and Herbarium, Korea National Arboretum, 415, Gwangneungsumogwon-ro, \\ Sohol-eup, Pocheon-si, Gyeonggi-do, Korea \\ (Received 22 April 2016; Revised 10 May 2016; Accepted 10 May 2016) \\ 한국산 솜다리속의 분류학적 재검토 \\ 이동혁 ${ }^{1,2} \cdot$ 박종수 $^{1} \cdot$ 최병희 ${ }^{1 *}$ \\ 1인천시 남구 인하로 100 인하대학교 생명과학과 \\ 2경기도 포천시 소흘읍 광릉수목원로 415 국립수목원 산림생물표본관
}

\begin{abstract}
Five species of the genus Leontopodium are recognized in Korea, but their taxonomic positions have been controversial. To clarify the taxonomic entity of these Korean species, we examined their morphological characters based on herbarium specimens and field observations. Valuable distinguishing characters for identification included the plant height, the basal shape of cauline leaves, the type and position of inflorescence, the types of hairs, the presence of leaves at the anthesis, and hairs on the phyllaries. Based on our observations, we were able to determine the taxonomic relationships between L. japonicum and its relatives, L. coreanum and L. hallaisanense. We also included the morphological characters of $L$. seorakensis in continuous variations of L. leiolepis, which we treated as synonyms. Consequently, we classified these Korean Leontopodium species into four taxa - L. coreanum var. coreanum, L. coreanum var. hallaisanense, L. leiolepis, and L. leontopodioides - with appropriate descriptions and illustrations.
\end{abstract}

Keywords: Korea, Leontopodium, var. coreanum, var. hallaisanense, L. leiolepis, L. leontopodioides

적 요: 한국산 솜다리속 (Leontopodium R. Br. ex Cassini)은 5종으로 기재되어 왔으나, 이들의 분류학적 위치에 대해서는 이견이 존재하였다. 이들의 분류학적 한계를 명확히 하고자 건조표본과 야외관찰등을 근거로 외부형 태학적 형질을 재검토하였다. 식물체의 높이, 경생엽 기부의 형태, 화서의 위치 및 형태, 털의 형태, 개화기 잎의 유무, 총포편 털의 형태 등은 한국산 솜다리속 분류군을 식별하는데 유용한 형질로 확인되었다. 이러한 외부형 태 형질을 바탕으로 왜솜다리 (L. japonicum) 및 근연분류군들 (L. coreanum, L. hallaisanense)의 분류학적 관계를 논의하였다. 또한 설악솜다리 (L. seorakensis)는 산솜다리 (L. leiolepis)의 형태적인 변이폭에 포함되므로, 이명으 로 처리하였다. 본 연구에서 한국산 솜다리속은 솜다리, 한라솜다리, 산솜다리, 들떡쑥(L. leontopodioides) 4분류 군으로 정리하였으며, 한국산 분류군의 검색표 및 각 종의 형질 기재와 도해를 제시하였다.

주요어: 한반도산, 솜다리속, 솜다리, 한라솜다리, 산솜다리, 들떡쑥

Well-known as "edelweiss", Leontopodium R. Br. ex Cassini (Asteraceae) is a small herbaceous genus comprising up to 41 species (Blöch et al., 2010). Its members are mostly distributed in the mountains of eastern Asia. However, two exceptions are the European species L. alpinum Cass. and L. nivale (Ten.) Huet ex Hand.-Mazz., which are the most prominent

\footnotetext{
*Author for correspondence: bhchoi@inha.ac.kr
} 
representatives of the genus. Originally, this genus was taxonomically reviewed in detail by two botanists, Beauverd (1912) and Handel-Mazzetti (1928). Notably, the monograph by the latter accepted 41 species that involved two subgenera (Paragnaphalium and Euleontopodium) and two sections (Nobilia and Alpina). Due to considerable variations and intermediate forms in morphology, however, the delimitation and phylogenetic relationships among species remain under dispute.

In Korea, five species (L. coreanum Nakai, L. leontopodioides Beauv., L. leiolepis Nakai, L. japonicum Miq., and $L$. hallaisanense Hand.-Mazz.) are currently recognized (Kim, 2007). However, this species delimitation is still arguable. In particular, the taxonomic entity of three endemic species ( $L$. coreanum, L. leiolepis, and L. hallaisanense) has been questioned by some authors (c.f., Lee, 1996; Lee and Park, 2008; Lee et al., 2010; Lim et al., 2012). For example, $L$. coreanum was first recognized by Nakai (1917) from Mt. Keumgang in North Korea, and was thought to be similar to Japanese L. japonicum (Nakai, 1920). Subsequently, however, this endemic species was treated as a synonym of either $L$. discolor Beauv. which was restrictively distributed in northern Japan and Sakhalin (Handel-Mazzetti, 1928; Grubov, 1990) or L. japonicum, which is widely distributed in China and Japan (Lee and Park, 2008). The current taxonomic understanding for $L$. coreanum is still inadequate. Likewise, L. hallaisanense was originally described from Mt. Halla by Handel-Mazzetti (1928), but some authors have questioned the validity of this species (Lee, 1996; Lee et al., 2010). Another endemic species, L. leiolepis, was recognized by Nakai (1920), and known to be restricted to North Korea and Mt. Seolak in South Korea. Recently, however, Lim et al. (2012) have described plants from Mt. Seolak as a new species, L. seorakensis Lim, Hyun, Kim \& Shin.

We might attribute these taxonomic arguments to a lack of knowledge about efficient diagnostic characteristics and considerable variations in morphology. Indeed, except for revisions by Lee et al. (1985), most previous work with Korean Leontopodium (e.g., Chung, 1956; Lee, 1980; Kim, 2007) since Nakai's declarations $(1917,1920)$ relied upon only simple descriptions of the regional flora. Although karyological and molecular studies have also been conducted for Korean Leontopodium (Lee et al., 2010, 2011; Jeon et al., 2015), its taxonomic treatment is still controversial.

Korean Leontopodium species are also listed as endangered species in the Rare Plant Data Book of Korea (Korea Forest Service, 2008), as follows: CR (Critically Endangered), $L$. leiolepis and L. hallaisanense; VU (Vulnerable), L. japonicum and L. leontopodioides; or DD (Data Deficient), L. coreanum. Therefore, establishing suitable management strategies for such endangered plants means that their unclear taxonomic entities must first be resolved. Here, we examine the comprehensive morphological characters of Korean Leontopodium species and related taxa to clarify their taxonomic entity.

\section{Materials and Methods}

Samples of Korean Leontopodium species were collected from 2009 to 2012, and the voucher specimens were deposited in the herbarium of Inha University (IUI). To examine morphological characters, we also studied dry specimens in herbaria at the Chinese Academy of Sciences, Beijing (PE); Kangwon National University (KWNU); Korea National Arboretum (KH); Kyoto University (KYO); National Institute of Biological Resources (KB); Seoul National University, College of Natural Sciences (SNU); and Tokyo University (TI). Qualitative and quantitative morphological characters were observed with a microscope (Leica MZ8, Leica DC300 System) and Digimatic calipers (Mitutoyo). Several diagnostic characters were also illustrated.

\section{Results and Discussion}

\section{Morphological characteristics of Korean Leonto- podium}

Stem: All four Korean Leontopodium taxa have both flowering and sterile stems. Whereas the flowering stems of $L$. coreanum var. coreanum and var. hallaisanense become lignified and firm over time, those of the two species within sect. Alpina ( $L$. leiolepis and $L$. leontopodioides) remain herbaceous and flexible. Samples of $L$. leontopodioides can be distinguished from other species (acaulescent form) by their erect and flecuous form of sterile stems and lack of radical leaves. In addition, $L$. leiolepis is well-classified by the presence of glandular hairs on flowering stems (Table 1).

Cauline leaves: Except for L. leiolepis, the basal leaves of the flowering stems are generally withered at anthesis. In terms of the base shape of the cauline leaf, the two species in sect. Alpina - L. leontopodioides and L. leiolepis - are sheathed while those in sect. Nobilia are unsheathed, a difference that corresponds to the system of Handel-Mazzetti (1928). Thus, the shape of the leaf base might be valuable for interspecific delimitations as well as classifications of the genus, and has already been used for investigating the phylogenetic relationships of a related genus, Anaphalis DC. (Nie et al., 2013). On average, 
Table 1. Comparison of morphological characters for selected Korean Leontopodium species.

\begin{tabular}{|c|c|c|c|c|c|}
\hline & & $\begin{array}{l}\text { L. coreanum var. } \\
\text { coreanum }\end{array}$ & $\begin{array}{l}\text { L. coreanum var. } \\
\text { hallaisanense }\end{array}$ & L. leiolepis & L. leontopodioides \\
\hline \multirow[t]{3}{*}{ Stem } & Height $(\mathrm{cm})$ & $15.5-31.5$ & $8.5-11.3$ & $6.0-11.5$ & $23.0-42.0$ \\
\hline & $\begin{array}{l}\text { Presence of } \\
\text { glanduar hair }\end{array}$ & densely pubescent & densely pubescent & $\begin{array}{l}\text { densely pubescent with } \\
\text { glandular trichomes }\end{array}$ & densely pubescent \\
\hline & Lignification type & becoming ligneous basally & becoming ligneous basally & herbaceous & herbaceous \\
\hline \multirow{8}{*}{$\begin{array}{c}\text { Leaf } \\
\text { of } \\
\text { flowering } \\
\text { stem }\end{array}$} & Length (mm) & $30.6-71.5$ & $19.2-20.8$ & $16.0-22.8$ & $22.9-35.6$ \\
\hline & Width (mm) & $6.1-13.7$ & $5.0-7.2$ & $3.0-5.5$ & $3.6-6.3$ \\
\hline & Number & $7-21$ & $9-11$ & $5-9$ & $12-22$ \\
\hline & Shape & $\begin{array}{l}\text { lanceolate, narrowly } \\
\text { oblong, oblong }\end{array}$ & $\begin{array}{l}\text { elliptical, ovate, } \\
\text { oblanceolate }\end{array}$ & $\begin{array}{c}\text { spatulate, oblanceolate, } \\
\text { lanceolate }\end{array}$ & $\begin{array}{l}\text { linear-lanceolate, } \\
\text { oblanceolate }\end{array}$ \\
\hline & Apex & acute, acuminate & acute, acuminate & $\begin{array}{l}\text { mucronate, rounded, } \\
\text { acuminate }\end{array}$ & mucronate, acute \\
\hline & Base & attenuate & attenuate & attenuate & attenuate, rounded \\
\hline & Sheathing & no sheathing & no sheathing & sheathing & sheathing \\
\hline & Fugacity of basal leaf & deciduous & deciduous & persistent & deciduous \\
\hline Inflorescence & Number of heads & $7-19$ & $7-8$ & $5-9$ & $1-4$ \\
\hline \multirow[t]{4}{*}{ Bract } & Length (mm) & $11.3-18.9$ & $13.5-16.3$ & $11.3-17.3$ & $12.3-21.4$ \\
\hline & Width (mm) & $3.3-6.6$ & $4.9-5.0$ & $2.7-4.3$ & $3.2-6.4$ \\
\hline & Shape & $\begin{array}{c}\text { oblong-lanceolate, } \\
\text { ovate }\end{array}$ & $\begin{array}{l}\text { elliptical, oval, } \\
\text { oblanceolate }\end{array}$ & $\begin{array}{c}\text { spatulate, oblanceolate, } \\
\text { lanceolate }\end{array}$ & linear, oblong \\
\hline & Hair & $\begin{array}{l}\text { both surfaces densely } \\
\text { pubescent }\end{array}$ & $\begin{array}{l}\text { both surfaces densely } \\
\text { pubescent }\end{array}$ & $\begin{array}{l}\text { more densely upper } \\
\text { surface cobwebby }\end{array}$ & $\begin{array}{c}\text { both surfaces densely } \\
\text { pubescent }\end{array}$ \\
\hline Phyllary & Hair & densely pubescent & densely pubescent & sparsely glandular & densely pubescent \\
\hline Achene & Length (mm) & $1.2-1.6$ & $0.9-1.3$ & $0.9-1.7$ & $0.9-1.0$ \\
\hline Pappus & Length (mm) & $2.6-3.0$ & $2.4-2.8$ & $2.4-3.1$ & $3.6-4.6$ \\
\hline Flowering & & Jul. to Aug. & Jul. to Aug. & May to Jun. & May to Jun. \\
\hline
\end{tabular}

the cauline leaves are longest for $L$. coreanum var. coreanum, followed in order by L. leontopodioides, L. coreanum var. hallaisanense, and L. leiolepis. The morphological characters for $L$. coreanum var. coreanum, such as the number of cauline leaves (12-21), leaf length (30.6-71.5 mm), and length of internode $(9.6-25.0 \mathrm{~mm})$ are distinguished from those of $L$. japonicum (number: 19-29; leaf length: 26.7-50.6 mm; length of internode: 5.8-11.6 mm) (Table 1, 2).

Capitula: The capitula of $L$. leontopodioides, dioecious and rarely heterogamous, are generally positioned at the top or in the axilla of flowering stems, with one to four heads. The other species feature densely or loosely solitary corymbous heads on the top of the flowering stems. The capitulum is approximately twice as large for L. leontopodioides than for the others (Table 1).

Phyllaries: The abaxial surfaces of phyllaries are densely pubescent for most Korean Leontopodium species, the exception being L. leiolepis, which has glabrous but sparsely glandular hairs. This characteristic of glandular hairs on flowering stems clearly separates L. leiolepis from the other Korean Leontopodium species. Lim et al. (2012) have described plants collected from Mt. Seolak as a new species L. seorakensis Lim, Hyun, Kim \& Shin - that is distinct from L. leiolepis based on the sparsely glandular outer phyllaries that are of similar size and shape in other species. However, we found no significant difference among them in this review (Table 1).

Ovary: The Korean Leontopodium species, including $L$. coreanum, have hairs on the ovaries of both the disk and marginal florets, although the density of those hairs differs somewhat among species. For L. coreanum, we found that the ovaries of the disk florets have hairs during fruiting periods, whereas the surface of ovary is looks like glabrous initially, and is distinguished from glabrous ones of $L$. japonicum (Table 2). 
Table 2. Comparison of morphological characters for L. coreaum and its relatives species.

\begin{tabular}{lccc}
\hline \hline & $\begin{array}{c}\text { L. coreanum } \\
\text { (type locality) }\end{array}$ & $\begin{array}{c}\text { Populations of } \\
\text { South Korea }\end{array}$ & $\begin{array}{c}\text { L. japonicum } \\
\text { (China \& Japan) }\end{array}$ \\
\hline Number of cauline leaves & $7-16$ & $7-21$ & $19-29$ \\
Length of cauline leaves (mm) & $32.7-55.4$ & $30.6-71.5$ & $26.7-50.6$ \\
Width of cauline leaves (mm) & $8.7-13.6$ & $6.1-13.7$ & $7.2-11.3$ \\
Length of internode (mm) & $11.4-19.8$ & $9.6-25.0$ & $5.8-11.6$ \\
Hairs on ovary of disk florets & thinly pubescent at fruiting period thinly pubescent at fruiting period & glabrous \\
Base of pappus & basally connate to ring & basally connate to ring & basally connate to ring \\
Chromosome number & - & $2 \mathrm{n}=28$ & $2 \mathrm{n}=26$ \\
\hline
\end{tabular}

\section{Taxonomic treatment}

Leontopodium R. Br. ex Cassini, Bull. Sci. Soc. Philom. Paris. 144, 1819. Type. L. alpinum Cass.

Korean name: 솜다리속 Som-da-ri-sok

Perennial herbs. Stem pubescent, rarely glandular. Leaves alternate, sessile, tomentose to villose or cobwebby hair; margin entire. Capitula heterogamous, rarely dioecious, disciform, in dense or loose terminal corymbs. Bracteal leaves similar with upper cauline leaves, white to grayish or yellowish tomentose. Phyllaries usually 3-seriate, papery, monomorphic, brownish, transparent. Marginal florets yellow, pistillate, filiform, outnumbering the disk florets. Disk florets functionally male; corolla yellow, 5-lobes erect, sparsely glandular in apex of the lobes. Anthers ecalcarate, with short tails. Pollen gnaphalioid. Style bifid; style-branches truncate with densely hirsute stigmatic surface separated. Achenes glabrous to papillose or pubescent. Pappus basally connate to ring, barbellate, capillary bristles.

\section{A key to the Korean species of Leontopodium}

1. Lower part of flowering stems becoming ligneous; cauline leaves not sheathing basally; usually flowering July to August

1. L. coreanum

1. Lower part of flowering stems herbaceous; cauline leaves sheathing basally; usually flowering May to June

2. Plant height usually $6.0-11.5 \mathrm{~cm}$; flowering stem covered with glandular and cobwebby hairs; basal leaves of flowering stem were persisted at anthesis; outer phyllaries abaxially glabrous with sparsely glandular; pappus $2.4-3.1 \mathrm{~mm}$ long

2. L. leiolepis

2. Plant height $23-42 \mathrm{~cm}$; flowering stem covered with cobwebby hairs; basal leaves of flowering stem were generally withered at anthesis; outer phyllaries abaxially densely pubescent; pappus 3.6-4.6 mm long

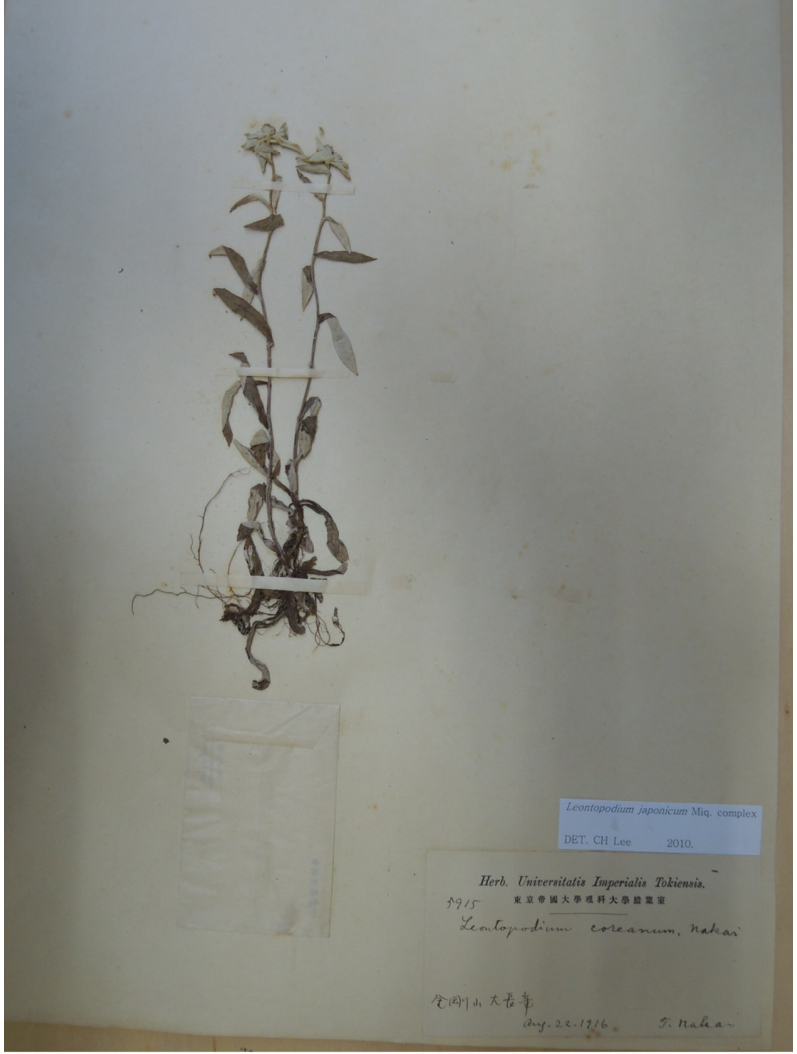

Fig. 1. Lectotype of Leontopodium coreanum Nakai (T. Nakai $5915, \mathrm{TI})$.

1. Leontopodium coreanum Nakai, Bot. Mag. Tokyo 31: 109. 1917. Type. Korea, Gangwon-do, Daejangbong, Aug. 22, 1916, T. Nakai 5915 (Lectotype, designated here, TI!, see Fig. 1). Remaining syntypes. Korea, Gangwon-do, Manggundae, Aug. 9, 1918, T. Nakai 5914 (TI); Korea, Gangwon-do, Birobong, Aug. 16, 1916, T. Nakai 5916 (TI!)

\section{A key to the varieties of $L$. coreanum}

1. Plant height $15.5-31.5 \mathrm{~cm}$; cauline leaves of middle part 30.6-71.5 mm long, lanceolate, narrowly oblong, oblong; 
densely or loosely corymbous heads; bracteal leaves oblong-lanceolate, ovate

var. coreanum

1. Plant height $8.5-11.3 \mathrm{~cm}$; cauline leaves of middle part ca. $2 \mathrm{~cm}$ long, elliptical, ovate, oblanceolate; densely corymbous heads; bracteal leaves elliptical, oval, oblaceolate

var. hallaisanense

\section{Var. coreanum}

Korean name: 솜다리 Som-da-ri
Perennial herbs. Rhizome prostrate, branching, with flowering and sterile stems. Stems erect, $15.5-31.5 \mathrm{~cm}$ tall, internodes $9.6-25.0 \mathrm{~mm}$, lower half somewhat becoming woody, pubescent. Leaves alternate, 7-21, 30.6-71.5 mm long, $6.1-13.7 \mathrm{~mm}$ wide, upper surface of leaves green and thinly tomentose, lower surface of leaves whitish tomentose, lanceolate, narrowly oblong, oblong, margin entire, apex acute to acuminate, base abruptly narrowed, sessile, basal leaves deciduous at flowering periods. Inflorescence solitary or

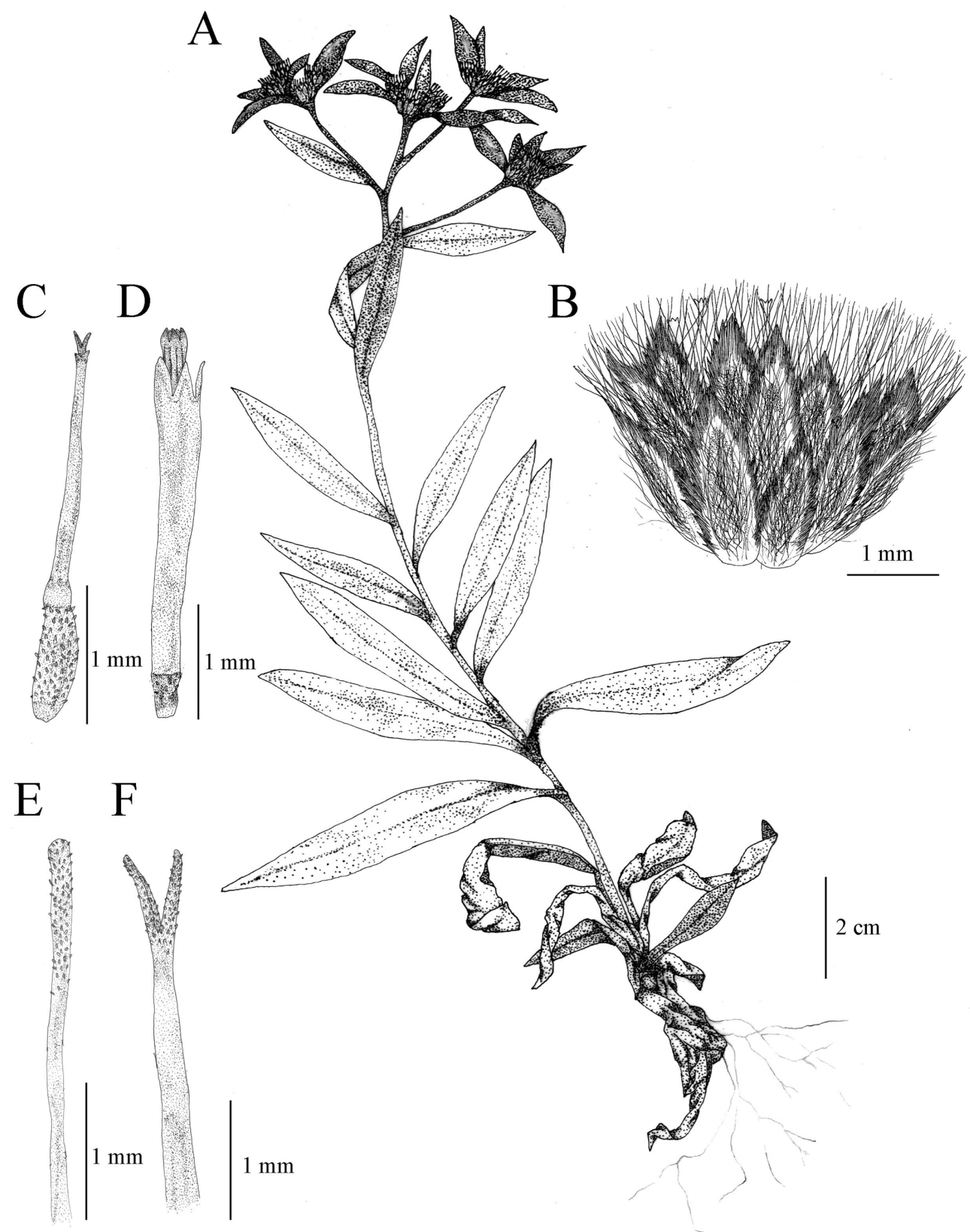

Fig. 2. Illustrations of Leontopodium coreanum Nakai. A. Habit; B. Capitulum; C. Marginal floret; D. Disk floret; E. Style of disk floret; F. Style of marginal floret. 
branched on flowering stems. Heads 7-19, arranged in compact or sparse terminal corymbs. Bracteal leaves $11.3-18.9 \mathrm{~mm}$ length, 3.3-6.6 $\mathrm{mm}$ wide, usually smaller than cauline leaves, oblong-lanceolate, ovate, both surfaces densely pubescent. Involucre subglobose, $4-5 \mathrm{~mm}$ high, $3.0-4.8 \mathrm{~mm}$ across; phyllaries 3-seriate, acute, margin brownish scarious, densely hairly dorsally. Marginal florets female, capillary, 5-lobed with ciliolate; stigma bifid, densely hirsute; ovary densely papillose. Disk florets bisexual, corolla subtubular, 5-lobed, yellowish, sterile; stigma densely hirsute; ovary thinly hirsute apex; anther basal sagittae. Achenes 1.2-1.6 mm long, papillose. Pappus of capillary bristle, $2.6-3.0 \mathrm{~mm}$ length. Flowering July-August. Fruit August-September (Fig. 2).

Distribution: Endemic to Korea. Gangwon-do, Gyeonggi-do, Chungcheongbuk-do, Gyeongsangbuk-do. Growing on alpine meadow or forest on northward from central Korea.

Taxonomic note: The taxonomic entity of Leontopodium coreanum Nakai has long been confused with its congener $L$. japonicum, which is widely distributed in East Asia. Plants of $L$. coreanum were first recognized by Nakai (1917) as endemic to Mt. Keumgang of Gangwon-do. Subsequently, Nakai (1920) described its morphology as very similar to Japanese $L$. japonicum, being distinguished by its leaf shape, minute amount of hairs on the ovaries of disk florets, and a liberal base for the pappus, when compared with plants of Japanese L. japonicum. Nevertheless, those two taxa have not been previously distinguished definitively due to subtle morphological differences, and the taxonomic entity of plants in South Korea also remains unclear - whether L. coreanum or L. japonicum. Accordingly, those two taxa have been recorded together in most regional floras of Korea (e.g., Lee, 1980; Lee, 1996; Kim, 2007), whereas a previous monograph by Handel-Mazzetti (1928), as well as floras for China (Chen et al., 2011) and Japan (Koyama, 1995) restricted the distribution of L. japonicum to those two countries.

In this study, our morphological comparisons suggested that the plants of South Korea are closely related to L. coreanum, and should be treated as an independent species rather than conspecific with L. japonicum of China and Japan, based on its diagnostic characters (Table 2). Although the character for the liberal base of the pappus, generally observed in other genera (e.g., Anaphalis DC. and Pseudognaphalium Kirp.), is not adequate for species of Leontopodium, the other morphological characters for populations in South Korea are similar to those of the type locality, Mt. Keumgang. In particular, the character for hairs on the ovaries of disk florets distinguishes plants of South Korea as well as $L$. coreanum from L. japonicum (Table 2). In contrast to a previous proposal by Lee and Park (2008), which treated L. coreanum as a synonym of $L$. japonicum based on the glabrous achenes in both taxa, we determined that $L$. coreanum, which has hairs on the ovaries of the disk florets during fruiting, is distinct from the glabrous samples of L. japonicum that we examined here. Furthermore, the taxonomic boundary of L. coreanum is clearly supported by our previous cytological study (Korea: $2 \mathrm{n}=28$; Japan: $2 \mathrm{n}=26$; Lee et al., 2010) and by molecular data for genetic divergence (China and Japan: 0.471, Korea and China: 0.742, Korea and Japan: 0.846, unpubl. data), thereby implying differentiation of the Korean populations. Based on this evidence, we suggest that $L$. coreanum, closely related to L. japonicum, is in the process of differentiation (e.g, allopatric speciation due to oceanic barriers), and must be accepted as an independent species in accordance with a treatment by Nakai (1917). However, when considering the regional morphological variations (China: var. saxatile, var. microcephalum; Japan: var. perniveum, var. shiroumense, var. spathulatum) as well as the wide distributional ranges of $L$. japonicum, further details, e.g., molecular and micromorphological data for their phylogenetic relationships, are

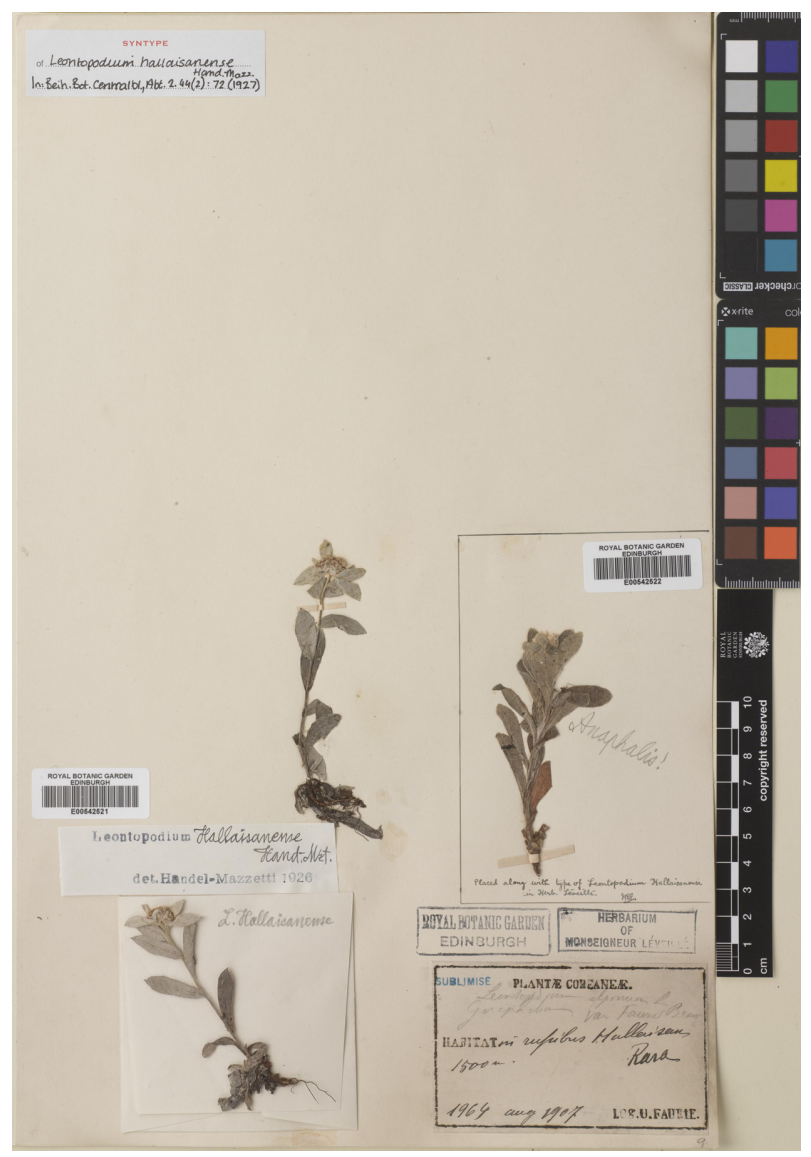

Fig. 3. Lectotype of Leontopodium coreanum var. hallaisanense (Hand.-Mazz.) D.H. Lee \& B.H. Choi (U. Faurie 1964, E). 
needed. Although Handel-Mazzetti (1928) treated L. coreanum as a synonym of $L$. discolor, without discussion, several characteristics of the former, including its oblanceolate cauline leaves and glabrous achenes, provide sufficient distinction from L. discolor (lineari-ovate cauline leaves and pubescent achenes), as found in our morphological examination. For now, we are making provisional decisions about those South Korean plants as belonging to $L$. coreanum, due to their similarities in diagnostic characters. In the protologue, Nakai (1917) indicated three original materials. We identified two of the original materials at TI, and selected one (T. Nakai 5915) having complete information in accordance with the protologue as lectotype (ICN Art. 9.2, 9.5, 9.12, McNeill et al., 2012).

Var. hallaisanense (Hand.-Mazz.) D.H. Lee \& B.H. Choi, comb. stat. nov.

Leontopodium hallaisanense Hand.-Mazz. Beih. Bot. Centralbl. 44: 72. 1928. Type. Korea, Jeju Isl. Aug. 1907, U.
A

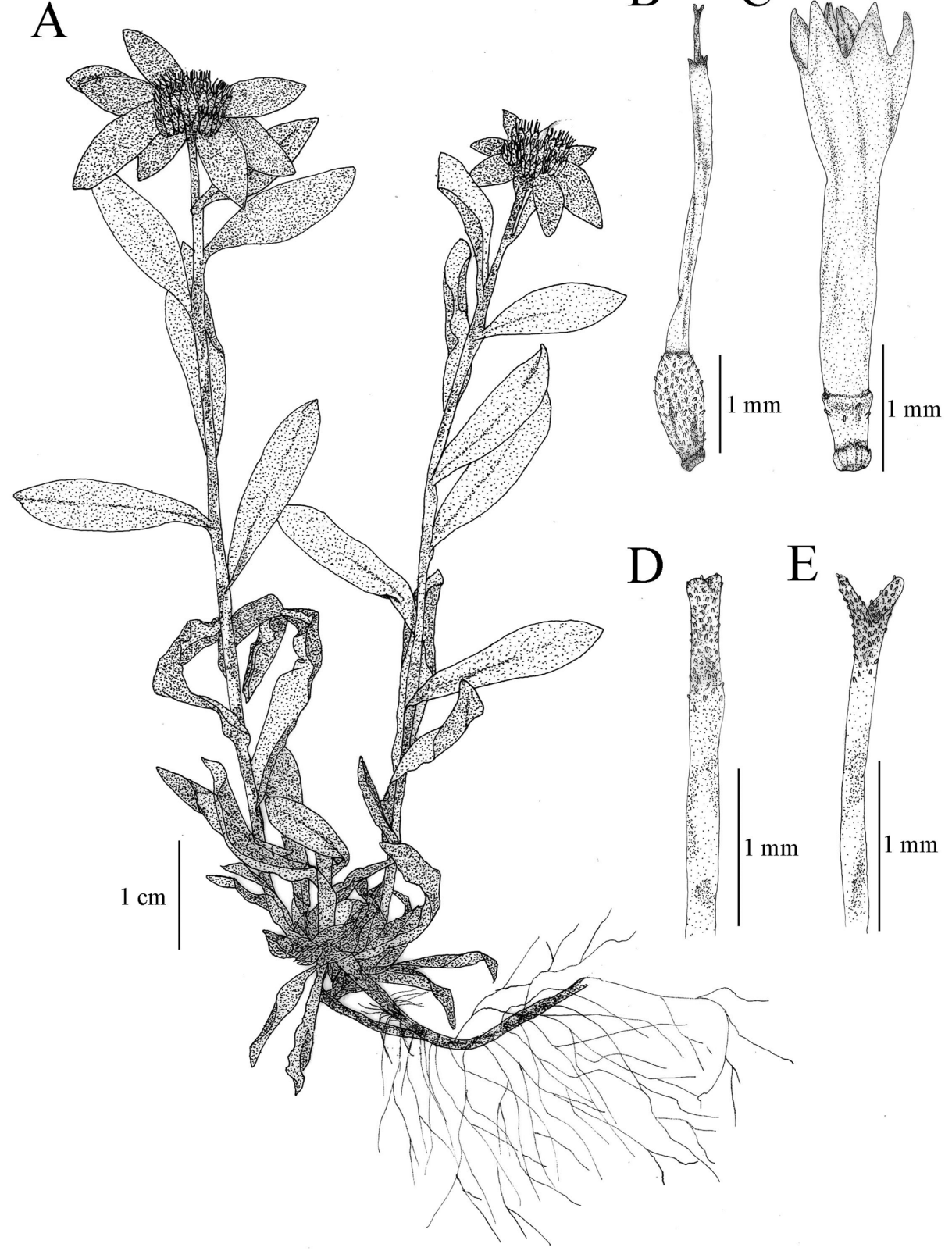

Fig. 4. Illustrations of Leontopodium coreanum var. hallaisanense (Hand.-Mazz.) D.H. Lee \& B.H. Choi. A. Habit; B. Marginal floret; C. Disk floret; D. Style of disk floret; E. Style of marginal floret. 
Faurie 1964 (Lectotype, designated here, E, see Fig. 3). Remaining syntype. Korea, Jeju Isl. Aug. 1907, U. Faurie 1967 (LE, seen as photo!; G, seen as photo!).

Korean name: 한라솜다리 Hal-la-som-da-ri

Stems erect, $8.5-11.3 \mathrm{~cm}$ tall, pubescent, in lower part often somewhat ligneous. Leaves alternate, 9-11, 19.2-20.8 mm long, 5.0-7.2 mm wide, elliptical to ovate, oblanceolate. Inflorescence usually solitary on flowering stems. Heads 7-8, arranged in compact terminal corymbs. Bracteal leaves $13.5-16.3 \mathrm{~mm}$ length, $5 \mathrm{~mm}$ wide, elliptical, oval, oblanceolate. Involucre subglobose, 5.0-5.5 mm high, 4.5-5.5 mm across (Fig. 4).

Distribution: Endemic to Korea. Growing on summit of Mt. Halla on Jeju Isl.

Taxonomic note: Var. hallaisanense is currently restricted to the upper part of Mt. Halla, where only a few individuals $(\mathrm{n}<30)$ occur. These plants were originally described by Handel-Mazzetti (1928) as being an independent species that differed from $L$. japonicum based on plant height and shape of the bracts (Fig. 3). However, those characters are commonly found for Leontopodium (Ling, 1965), and some authors have questioned the validity of having a separate species (Lee, 1996; Lee et al., 2010). Indeed, such diagnostic characteristics have also been reported for several specimens from inland populations of $L$. coreanum, even though such types are rarely identified. Thus, it might not be sufficient to recognize it as an independent species. Although the number of examined specimens for $L$. hallaisanense has been limited, the results of our molecular analysis (Lee et al., unpubl. data) demonstrated that $L$. hallaisanense was nested within $L$. coreanum. Therefore, we suggest that var. hallaisanense be considered an 'insular form' of $L$. coreanum, differentiated by diagnostic characteristics as key, and should be treated as a variety of that species. Furthermore, previous reports of the distribution of Leontopodium species at Mt. Halla [L. japonicum: upper area of Mt. Halla (Nakai, 1913); L. coreanum: 1800-2100 m (Nakai, 1920)] may have led to a misidentification of var. hallaisanense. Therefore, further ecological and molecular analyses with more individuals are necessary if we are to develop a conservation strategy for the few plants $(n<30)$ that remain at the peak of Mt. Halla.

2. Leontopodium leiolepis Nakai in Matsumura, Icon. Pl. Koisikav. 4: 75. 1920. Type. Korea, Hamgyeongnam-do, Waigalbong, 2,200 m, Jul. 11, 1914, T. Nakai 1542 (Holotype, TI!, see Fig. 5).

Leontopodium seorakensis Lim, Hyun, Kim \& Shin, Korean J. Pl. Taxon. 42: 157. 2012. Syn. nov. Type. Korea,

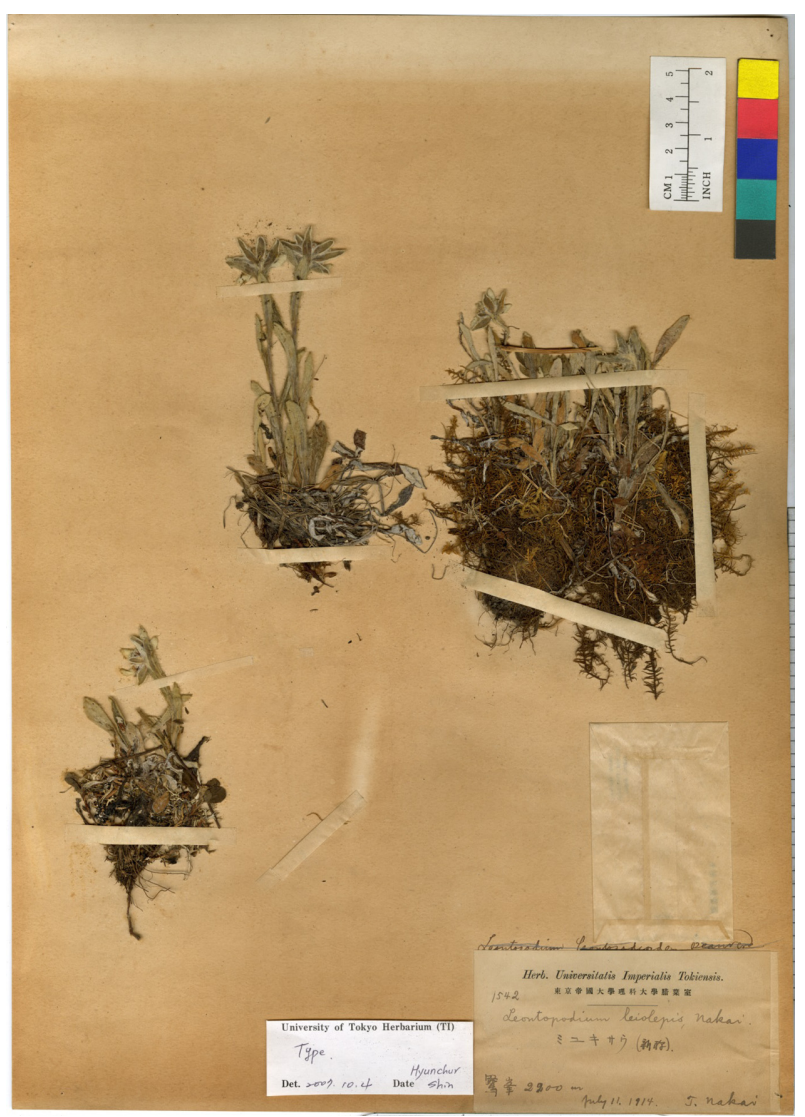

Fig. 5. Holotype of Leontopodium leiolepis Nakai (T. Nakai 1542, $\mathrm{TI})$.

Kangwon-do, Inje-gun, near the peak of Mt. Ahn (1,396 m) area in Mt. Seolak National Park, $1,360 \mathrm{~m}$ elev., N $38^{\circ} 08^{\prime} 10.2^{\prime \prime}$, E $128^{\circ} 20^{\prime} 4.2^{\prime \prime}, 30$ Jun. 2007, Hyun 20070004 (Holotype, KB; Isotype, SNU).

\section{Korean name: 산솜다리 San-som-da-ri}

Perennial herbs. Rhizome prostrate, branching, with flowering and sterile stems. Stems erect, $6.0-11.5 \mathrm{~cm}$ tall, woolly hair and glandular. Leaves alternate, 5-9, 16.0$22.8 \mathrm{~mm}$ long, 3.0-5.5 mm wide, upper surface of leaves thinly tomentose, lower surface of leaves whitish arachnoid and glandular, both sides becoming sometimes calvescent, spatulate, linear or oblanceolate, margin entire, apex mucronate, base attenuate, sheathing stems, radical and basal cauline leaves present at flowering periods. Inflorescence solitary on flowering stems. Heads 5-9, densely arranged. Bracteal leaves 11.3-17.3 mm length, 2.7-4.3 mm wide, more or less smaller than cauline leaves, linear or oblanceolate, upper surface densely floccose, lower surface thinly arachnoid. Involucre subglobose, $5.0-5.5 \mathrm{~mm}$ high, $3.5-4.5 \mathrm{~mm}$ across; phyllaries 3-seriate, $3.0-4.3 \mathrm{~mm}$ long, $1.1-1.4 \mathrm{~mm}$ wide, acute, 
margin brown to reddish brown scarious, glabrous, sparsely glandular. Marginal florets female, corolla capillary, 4-lobed with sparsely ciliolate; style cylindrical; stigma bifid, densely hirsute; ovary densely papillose. Disk florets bisexual, corolla subtubular, 5-lobed, yellowish, sterile; style cylindrical; stigma clavellate, densely hirsute; ovary pubescent; stamens 5; anther basal sagittate. Achenes 0.9-1.7 mm long, papillose. Pappus of capillary bristles, 2.4-3.1 mm length. Flowering May-June. Fruit July-August (Fig. 6).
Distribution: Endemic to Korea. Hamgyeongbuk-do, Hamgyeongnam-do, Pyeonganbuk-do, Gangwon-do. Rock crevice on high mountains of northern and central Korea.

Taxonomic note: L. leiolepis was identified by Nakai (1920) from samples collected at Waigalbon (2,200 m) in North Korea, and was considered an endemic species distributed northward from Mt. Seolak in South Korea. Recently, however, Lim et al. (2012) have described plants from Mt. Seolak as a new species, L. seorakensis Lim, Hyun, Kim \& Shin, separate from

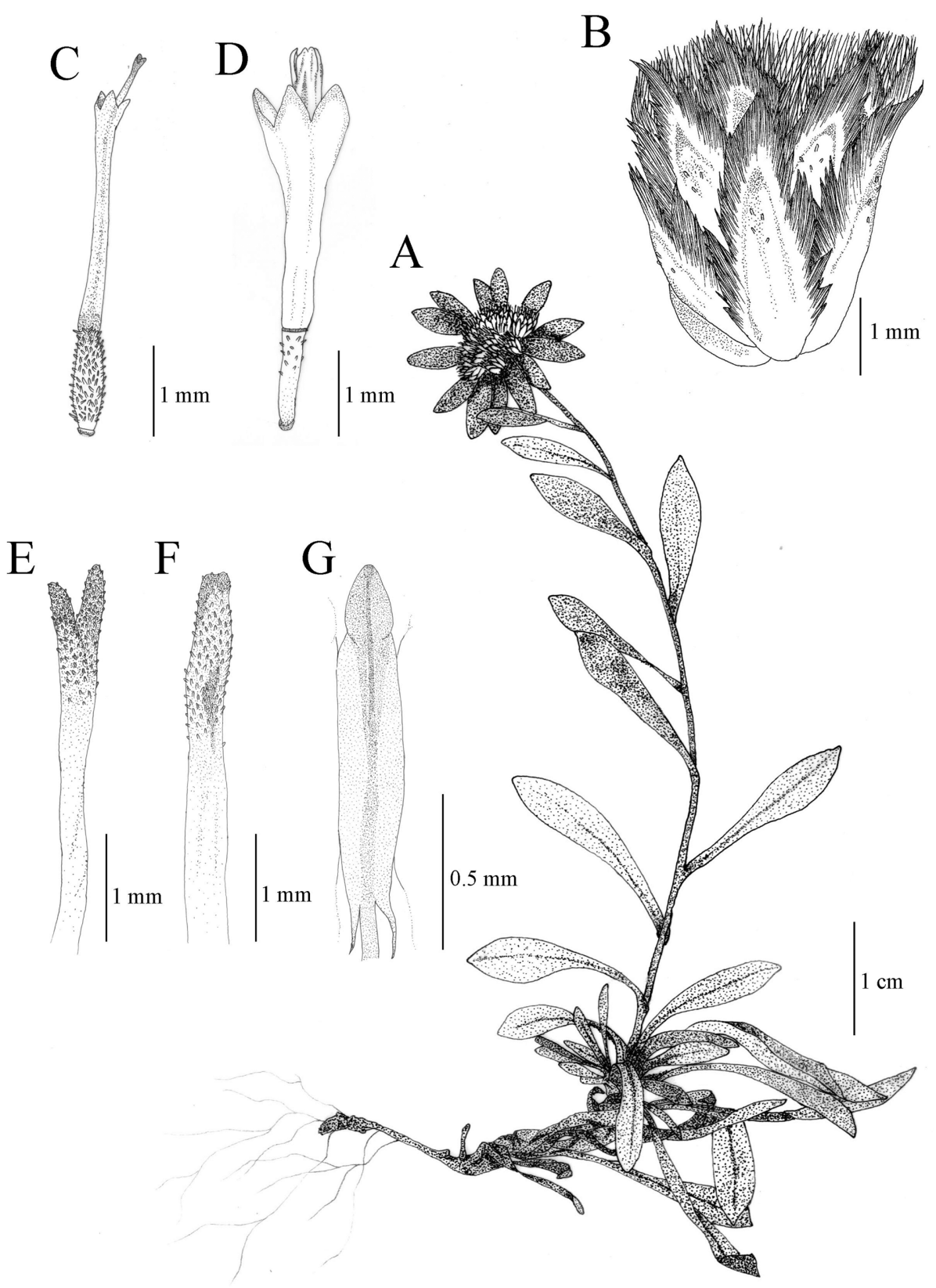

Fig. 6. Illustrations of Leontopodium leiolepis Nakai. A. Habit; B. Capitulum; C. Marginal floret; D. Disk floret; E. Style of marginal floret; F. Style of disk floret; G. Stamen of disk floret. 
L. leiolepis. In their protologue, they suggest that $L$. seorakensis is distinguished from the latter by morphological characters such as densely arachnoid hairs on the lower surface of bracteal leaves as well as sparsely glandular outer phyllaries that are of similar size and shape as the former. However, those diagnostic characteristics were already described and illustrated in the declaration for L. leiolepis by Nakai (1920) as "supra floccose infra aranea" and "deorso paruissime glandulosociliata". Indeed, specimens for L. leiolepis, including type materials, have almost glabrous and sparsely glandular hairs on the outer phyllaries that are easily distinguished from other Leontopodium species. Our morphological comparison between specimens from the type locality of $L$. seorakensis [locotype: Mt. Ahn, Jun. 12, 2009, D.H. Lee \& W.B. Cho 96015, 96018, 96019 (IUI!); D.H. Lee \& W.B. Cho 96017, 96020 (KH!)] and those of L. leiolepis, including the type specimen, also indicate no clear morphological discontinuities between the two species, but further support the merging of them (Table 3). Although several specimens collected in North Korea actually exhibited somewhat glabrous bracteal leaves, such variations as density of hairs on those leaves are relatively easily recognized within the genus as intraspecific variations (Ling, 1965). Moreover, the plant materials in both the type specimen of $L$. leiolepis (Fig. 5) and the type locality of $L$. seorakensis have almost glabrous and arachnoid bracteal leaves. In fact, the glabrous bracts are mostly observed in plants during fruiting periods, and we assume that this variation in density might be influenced by the time when they were collected (i.e., flowering: arachonid; fruiting: thinly arachnoid to almost glabrous). Another morphological character for $L$. seorakensis is also ambiguous. Lim et al. (2012) have stated that the length and shape of the outer and inner phyllaries are similar in L. seorakensis, but no exact quantitative values exist. In contrast, our examinations indicated that this species also has slightly narrow and longer inner phyllaries when compared with the outer ones, and the ratio of lengths between inner and outer phyllaries for L. seorakensis $(1.06-1.28 \mathrm{~mm})$ does not differ much from that for L. leiolepis (1.14-1.36 mm; Table 3). Hence, we assume that the above diagnostic characters for $L$. seorakensis are not sufficient to describe it as a new species that is separate from L. leiolepis, despite their subtle differences. Rather, we might infer that those differences are just included in the intraspecific variations of L. leiolepis (Fig. 5) and, thus, we deduce here that $L$. seorakensis is a synonym of $L$. leiolepis.

Meanwhile, L. leiolepis has been classified within the subsection Kurilensia Hand.-Mazz., having glandular hairs on the stems that are similar to those of $L$. kurilense Takeda, which

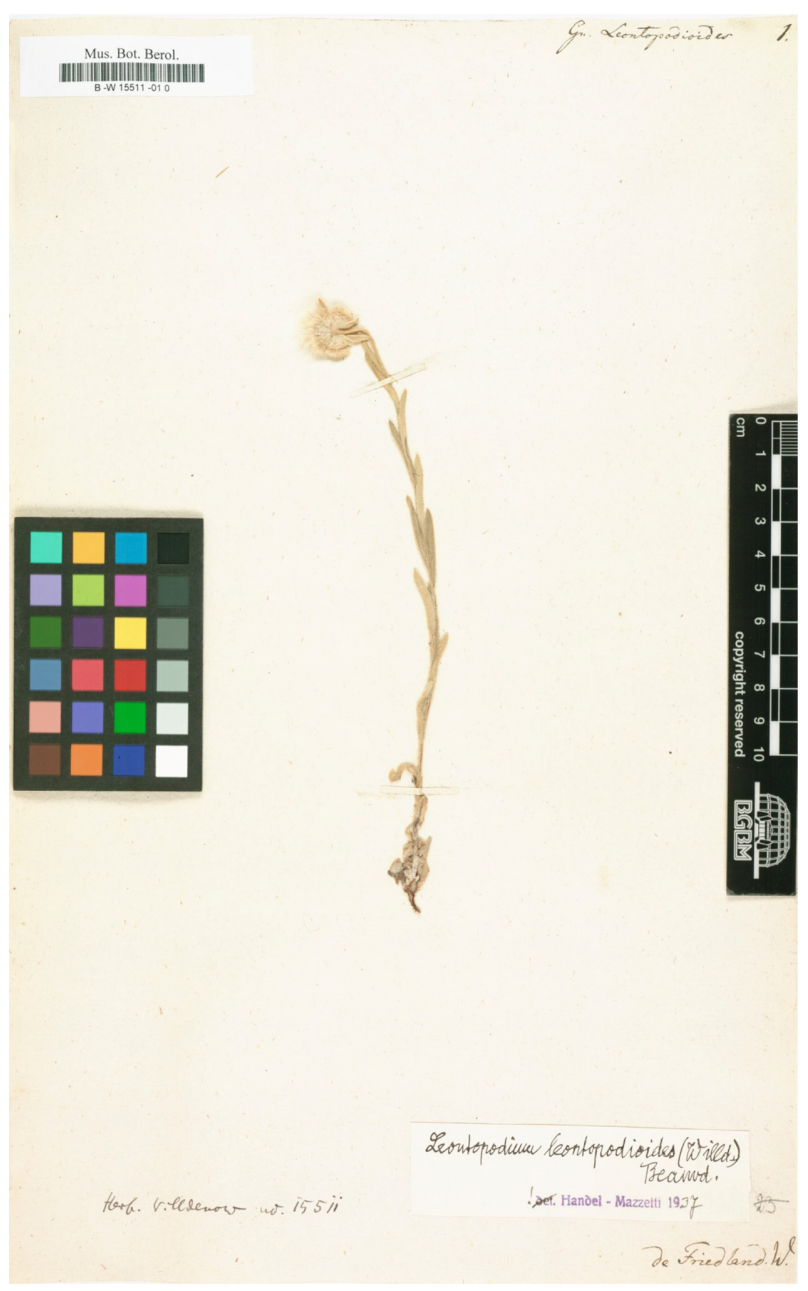

Fig. 7. Holotype of Leontopodium leontopodioides (Willd.) Beauverd (Willdenow s.n., BM).

Table 3. Comparison of morphological characters between L. leiolepis and L. seorakensis.

\begin{tabular}{lcc}
\hline \hline & L. leiolepis & L. seorakensis \\
\hline Shapes of cauline leaves & spatulate, linear or oblanceolate & spatulate, oblanceolate \\
$\begin{array}{l}\text { Ratio of lengths between inner } \\
\text { and outer phyllaries }\end{array}$ & $1.14-1.36$ & $1.06-1.28$ \\
Hairs on lower surface of bract & thinly arachnoid & thinly arachnoid \\
Hairs on outer phyllaries & sparsely glandular & sparsely glandular \\
\hline
\end{tabular}


is endemic to Japan (Handel-Mazzetti, 1928). Furthermore, several varieties (i.e., var. curvicollum and var. crinulosum) have been proposed for populations in North Korea (Im, 1999). However, its distribution and taxonomic relationships had not previously been evaluated. In addition, the isolated habitats of Mt. Seolak represent the South limit of its distribution range. Therefore, further molecular and population analyses are necessary if we are to gain broad knowledge about the phylogenetic relationships and conservation of this species.
3. Leontopodium leontopodioides (Willdenow) Beauverd in Bull. Soc. Bot. Geneve, Ser. 2, 1: 371. 1909. Type. Russia, Siberia, s.d. Willdenow s.n. (Holotype, BM, seen as photo!, Fig. 7)

Filago leontopodioides Willdenow, Phytogr. 12. 1794. Gnaphalium leontopodioides (Willdenow) Willdenow, Sp. Pl. 3: 1893. 1804. Antennaria leontopodioides (Willdenow) Nakai in Bull. Nat. Sci. Mus. Tokyo 31: 112. 1952.

Korean name: 들떡쑥 Deul-tteok-ssuk

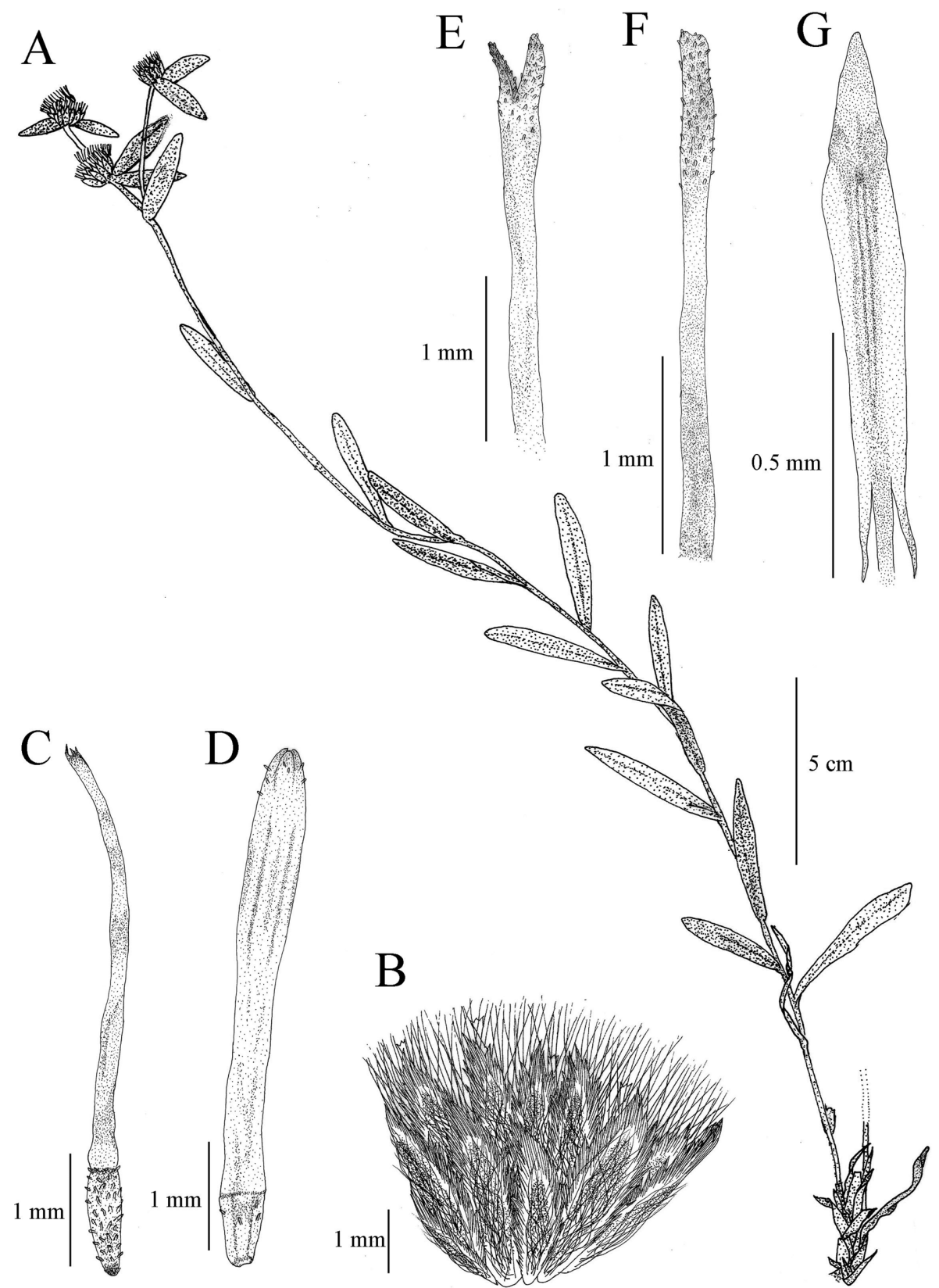

Fig. 8. Illustrations of Leontopodium leontopodioides (Willd.) Beauverd. A. Habit; B. Capitulum; C. Marginal floret; D. Disk floret; E. Style of marginal floret; F. Style of disk floret; G. Stamen of disk floret. 
Perennial herbs. Rhizome short, lignose, multicipital, with flowering and sterile stems, not radical leaves. Stems slender or erect, somewhat flexuous, $23-42 \mathrm{~cm}$ tall, covered with woolly hair, then becoming peeled. Leaves sparsely alternate, 12-22, similar in size and shape, 22.9-35.6 mm long, 3.6$6.3 \mathrm{~mm}$ wide, linear to lanceolate, apex rounded to mucronate, margin entire, base gradually narrowed, halfsheathing stem, upper surface greenish and thinly pubescent, lower surface densely pubescent. Inflorescence depauperate, top or axila on flowering stems. Heads $1-4$, dioecious. Bracteal leaves 1-4 per heads, smaller than cauline leaves, 12.3-21.4 mm long, 3.2-6.4 mm wide, linear to lanceolate, inner phyllaries more narrowed, colorless or brownish scarious, densely hairly dorsally. Achenes $0.9-1.0 \mathrm{~mm}$ length. Pappus uniseriate, $3.6-4.6 \mathrm{~mm}$ long, grayish white. Flowering May-June. Fruit July-August (Fig. 8).

Distribution: China, Korea, Mongolia, Russia.

Korea: Hamgyeongnam-do, Chungcheongbuk-do, Gyeongsangbuk-do, Gyeongsangnam-do. Sunny grassland on central Korea.

Taxonomic note: This species was first recorded as Filago leontopodioides Willdenow from Siberia before being transferred to the genus Leontopodium, i.e., $L$. leontopodioides (Willdenow) Beauverd. This treatment is now broadly accepted for plants in their distribution range of China, Mongolia, Russia, and Korea (Grubov, 1990; Kim, 2007; Chen et al., 2011). A Korean distribution was first recorded in Seoul by Palibin (1898) and assigned the name Gnaphalium leontopodioides. It has been also collected from Chinampo in the northern region of Korea (Beauverd, 1912; Handel-Mazzetti, 1928). Compared with other species in that genus, L. leontopodioides grows at relatively lower elevations (300-700 m) and has a wider distribution range. This taxon, being dioecious, is well-distinguished by inflorescences positioned at the top or axillary to the flowering stems. It lacks a pedicel and pappus and its flower heads are 1.5 times longer than those of other Leontopodium species.

\section{Acknowledgments}

The authors express our sincere thanks to curators of the following herbaria for assisting in our examination of the specimens used in this study: KB, KH, KWNU, KYO, PE, SNU, and TI. We are also grateful to our colleagues W.B. Cho, I.S. Choi, and D.P. Jin at the Plant Systematics Laboratory of Inha University for help in collecting the plant materials and making comments on this manuscript.

\section{Literature Cited}

Beauverd, G. 1912. Contribution à l'étude des Composées. Suite VI. Nouneaux Leontopodium et Raoulia. Bulletin de la Société botanique de Genève 5: 12-55. (in French)

Blöch, C., W. B. Dickoré, R. Samuel and T. F. Stuessy. 2010. Molecular phylogeny of the edelweiss (Leontopodium, Asteraceae: Gnaphalieae). Edinburgh Journal of Botany 67: 235264.

Chen, Y. S., S. X. Zhu and R. A. Bayer. 2011. Gnaphalieae. In Flora of China Vol. 20-21 (Asteraceae). Wu, X.Y., P.H. Raven and D.Y. Hong (eds.), Science Press (Beijing) \& Missouri Botanical Garden Press (St. Louis). Pp. 774-818.

Chung, T. H. 1956. Korean Flora. Sinjisa, Seoul. Pp. 712-713. (in Korean)

Grubov, V. I. 1990. Leontopodium R. Br. ex Cass. In Flora of the U.S.S.R. Vol. 25. Shishkin B.K. (ed.), Koeltz Scientific Books, Dehra Bun. Pp. 367-387.

Handel-Mazzetti, H. 1928. Systemarische monographie der gattung Leontopodium. Beihefte zum Botanischen Centralblatt 44: 1-178. (in German)

Im, R. J. 1999. Flora of Coreana 7. Science and Technology Publishing House, Pyongyang. Pp. 250-253. (in Korean)

Jeon, M. G., K. J. Choi and J. Y. Kim. 2015. Discrimination of the genus Leontopodium species (Gentianales: Asteraceae) based on RAPD. Journal of Forest and Environmental Science 31: 68-71.

Kim, K. J. 2007. Leontopodium. In The Genera of Vascular Plants of Korea. Park, C.-W. (ed.), Academy Publishing Co., Seoul. Pp. 1003-1005.

Korea Forest Service. 2008. Rare Plants Data Book in Korea. Korea National Arboretum. Pocheon. (in Korean)

Koyama, H. 1995. Leontopodium. In Flora of Japan Vol. IIIb. Iwatsuki, K., T. Yamazaki, D. E. Boufford and H. Ohba (eds.), KodanSha, Tokyo. Pp. 106-108.

Lee, C. and K. W. Park. 2008. Taxonomic reconsideration of the Leontopodium coreanum Nakai (Asteraceae). P. 196 (Abstract in Botany 2008).

Lee, D. H., G. Y. Chung and B. H. Choi. 2010. Chromosome number of four Korean species of Leontopodium (Asteraceae). Korean Journal of Plant Taxonomy 40: 153-156. (in Korean)

Lee, D. H., J. H. Lee and B. H. Choi. 2011. Isolation and characterization of 10 microsatellite loci from Korean Leontopodium japonicum (Asteraceae). American Journal of Botany 98: e183-e184.

Lee, K. E., W. C. Lee and C. H. Lim. 1985. Studies on certain growing aspects of wild genus Leontopodium distributed in Korea. Korean Journal of Horticultural Science and Technology 26: 59-65. (in Korean) 
Lee, T. B. 1980. Illustrated Flora of Korea. Hyangmunsa, Seoul. Pp. 727-728. (in Korean)

Lee, W. T. 1996. Lineamenta Florae Koreae. Academy Publishing Co., Seoul. Pp. 1169-1171. (in Korean)

Lim, Y. S., J. -O. Hyun, Y. -D. Kim and H. C. Shin. 2012. Leontopodium seorakensis, a new species of Asteraceae from Korea. Korean Journal of Plant Taxonomy 42: 157-160.

Ling, Y. 1965. Notulae de nonnulis generibus tribus Inulearum familiae Compositarum florae Sinicae. Acta Phytotaxonomica Sinica 10: 167-181. (in Chinese)

McNeill, J., F. R. Barrie, W. R. Buck, V. Demoulin, W. Greuter, D. L. Hawksworth, P. S. Herendeen, S. Knapp, K. Marhold, J. Prado, W. F. Prud'homme van Reine, G. F. Smith, J. H. Wiersema and N. J. Turland. 2012. International Code of Nomenclature for Algae, Fungi, and Plants (Melbourne Code) adopted by the Eighteenth International Botanical Congress,
Melbourne, Australia, 2011. Regnum Vegetabile Vol. 154. Koeltz Scientific Books, Knigstein.

Nakai, T. 1913. Flora of Quelpeart and Wangto Island. Government General of Chosen, Seoul. (in Japanese)

Nakai, T. 1917. Notulae ad plantas Japoniae et Koreae. XIV. Botanical Magazine (Tokyo) 31: 97-11.

Nakai, T. 1920. Icones Plantarum Koisikavenses or Figures with Brief Descriptive Characters of New and Rare Plants, Selected from the University Herbarium 4: 72-76. (in Japanese)

Nie, Z. L., V. Funk, H. Sun, T, Deng, Y. Meng, J. Wen. 2013. Molecular phylogeny of Anaphalis (Asteraceae, Gnaphalieae) with biogeographic implications in the Northern Hemisphere. Journal of Plant Research 126: 17-32.

Palibin, J. 1898. Conspectus Florae Koreae 1. Acta Horti Petropolitani 17: 1-5135. 


\section{Appendix. Specimens examined for Korean Leontopodium species and its relatives.}

Leontopodium coreanum Nakai var. coreanum KOREA. Gyeonggi-do: Gapyeong-gun, Mt. Unak, 17 Aug. 2009, D.H. Lee 98001 - 98004 (IUI); Gapyeong-gun, Mt. Unak, 6 Sept. 1992, J.H. Mun 389, 390 (SNU); Gangwon-do: Mt. Keumgang, Birobong, 30 Jul. 1928, K. Kondo 9384 (PE); Mt. Keumgang, 13 Aug. 1932, S. Kitamura s.n. (KYO); Mt. Keumgang, 27 Jul. 1933 , B.S. Toh \& H.J. Sim 14269 (SNU); Mt. Keumgang, 11 Aug. 1943, B.S. Toh 14264, 14268 (SNU); Mt. Keumgang, 5 Aug. $1932, ?$ 14270 (SNU); Gosung-gun, Mt. Hyangro-bong, 29 Aug. 1990, ? (IUI); Gosung-gun, Mt. Hyangro-bong, 1 Aug. 2008, J.O. Hyun \& H.J. Kwon NAPI-0337 (KH); Inje-gun, Mt. Seolak, 25 Aug. 2009, D.H. Lee \& W.B. Cho 98301 - 98316 (IUI); Inje-gun, Mt. Seolak, 24 Oct. 2004, J.O. Hyun \& H.K. Park 2004192 (KH); Inje-gun, Mt. Seolak, 15 Jul. 2005, E.S. Jeon ESJeon52257; Hongcheon-gun, Mt. Gachil, 23 Jul. 1999, G.Y. Chung et al. ANH990723-001; Pyeongchang-gun, Mt. Gariwang, 2 Jul. 2010 , J.Y. Lee \& J.H. Lee 107901 - 107914 (IUI); Wonju-si, Mt. Chiak, Sept. 1973, B.S. Toh \& H.J. Sim 47992 (SNU); Chungcheongbukdo: Danyang-gun, Mt. Sobaek, 22 Jul. 2009, D.H. Lee \& W.B. Cho 97201 - 97210 (IUI); Danyang-gun, Mt. Sobaek, 6 Aug. 1999, C.W. Park, H.W. Lee J. Koh 10679 (SNU); Danyang-gun, Mt. Sobaek, 17 Jul. 1999, C.W. Park, H.W. Lee J. Koh 10619 (SNU); Danyang-gun, Mt. Sobaek, 18 Aug. 2001, E.S. Jeon, S.H. Park \& S.G. Gwon s.n. (KH); Danyang-gun, Mt. Sobaek, 7 Aug. 1995, W.Y. Lee, S.S. Kim \& H.Y. Park s.n. (KH); Danyang-gun, Mt. Sobaek, 16 Sep. 2006, G.Y. Chung ANH060916-003 (KH); Mt. Dosol, 25 Jul. 1996, G.Y. Chung et al. ANH960725 - 001 (KH); Gyeongsangbuk-do: Mungyeong-si, Mt. Daeya, 3 Sep. 2009, D.H. Lee \& W.B. Cho 99001 - 99011 (IUI); Mungyeong-si, Mt. Daeya, 27 Jul. 2010, D.H. Lee 107801 - 107806 (IUI).

Leontopodium coreanum var. hallaisanense (Hand.-Mazz.) D.H.Lee \& B.H.Choi KOREA. Jeju-do: Jeju-si, Mt. Halla, 29 Aug. 2009, D.H. Lee \& W.B. Cho 98501, 98502 (IUI); Jeju-si, Mt. Halla, 18 Jul. 1935, B.S. Toh 14265 (SNU); Jeju-si, Mt. Halla, 12 Jul. 2007, J.H. Lee S0124 (KH).

Leontopodium leiolepis Nakai KOREA. Hamgyungbuk-do: Buyong, 20 Jul. 1939, T. Nakai s.n. (TI); Hamgyungnam-do: Mt. Nobong, 17 Aug. 1935, T. Nakai 15774 (TI); Pyeonganbuk-do: Mt. Myohyang, 20 Jul. 1938, B.S. Toh \& H.J. Sim 15228 (SNU); Gangwon-do: Inje-gun, Mt. Seolak, 21 May 1997, S.S. Kim \& D.N. Sin s.n. (KH); Inje-gun, Mt. Seolak, 27 May 2009, D.H. Lee \& W.B. Cho 95001, 95002 (IUI); Inje-gun, Mt. Seolak, 11 Jun. 2009, D.H. Lee \& W.B. Cho 96001 - 96014 (IUI); Inje-gun, Mt. Ahn, Mt. Seolak, 12 Jun. 2009, D.H. Lee \& W.B. Cho 96015, 96017, 96018, 96019, 96020 (IUI); Inje-gun, Mt. Seolak, 5 Jul. 2009, D.H. Lee 97001 - 97004 (IUI); Inje-gun, Mt. Seolak, 25 Aug. 2009, D.H. Lee \& W.B. Cho 98317 - 98319 (IUI).

Leontopodium leontopodioides (Willd.) Beauverd KOREA. Hamgyeongnam-do: ? 1938, S. Tsuya 4522 (TI); Chungcheongbukdo: Danyang-gun, Mt. Sobaek, 22 Jul. 2009, D.H. Lee \& W.B. Cho 97220 (IUI); Gyeongsangbuk-do: Cheongsong-gun, Mt. Mupo, 23 Jun. 2000, G.Y. Chung et al. ANH000623-001 (KH); Uiseong-gun, Mt. Bibong, 23 Jul. 2009, D.H. Lee \& W.B. Cho $97230-$ 97245 (IUI); Sangju-si, Mt. Deokam, 14 Jun. 2010, D.H. Lee 106518 - 106530 (IUI); Gyeongsangnam-do: Hapcheon-gun, Mt. Hwangmae, 5 Sep. 2009, D.H. Lee \& W.B. Cho 99051 - 99054 (IUI); Daegu-si: Dalseo-gu, Mt. Daeduk, 4 Jun. 2006, C.Y. Yoon Yoon 224 (KH). MONGOLIA. Selenge Aimag, 19 Jul. 2004, S. Y. Woo s.n. (KH); TUV Aimag, 21 Aug. 2001, Y.D. Ro \& J.O. Hyun 2001067 (KH). RUSSIA. Primorye, Kievska River bank, 19 Jul. 2002, B.Y. Sun et al. 2009 (KH); Primorsky Territory, Lazovsky, 7 Jul. 2001, K.A. Gozobets \& R.V. Doudkin s.n. (KH)

Leontopodium japonicum Miq. JAPAN. Iwate: Mt. Iwate, 10 Aug. 1909, S. Yajima 6006 (KH); Oshu, Mt. Yakeishi, 24 Aug. 1962, H. Koyama 1393 (KYO); 24 Aug. 1973, M. Takahashi s.n. (TI); Nagano: Utukushigabara, 9 Aug. 1992, G, Murata 70904 (KYO); Ohshika-mura, Tsubakuroiwa, 21 Aug. 1965, T. Yamazaki 9924 (TI); Komoro-shi, Takamine, 22 Aug. 1985, Z. Sato s.n. (TI); Shinoina-gun, 4 Aug. 1966, M. Furuse 44354 (PE); Gunma: Minakami, Mt. Tanigawa, 16-17 Jul. 1973, S. Kurata \& T. Nakaike 10050 (KYO); Annaka-shi, Mt. Myogi, G. Murata 27489 (TI); Mt. Akagi, 13 Jul. 2010, D.H. Lee 107501 - 107510 (IUI); Miyagi: Sendai, Mt. Funagata, 8 Jun. 1961, H. Ohashi 610734 (KYO); Shiroi-shi, Mt. Zao, 14 Aug. 1931, S. Saito s.n. (TI); Mt. Fubo, 28 Jul. 1985, B.H. Choi s.n. (IUI); Saitama: Chichibu-gun, Mt. Futagoyama, 16 Aug. 1986, J. Murata, H.T. Im \& C.S. Chang 21559 (TI). CHINA. Hupeh: Shenlungkai, ?, K.S. Chow 76028 (TI); Shaanxi: ?, C.H. Wang 552 (PE); ?, T.S. Wang 16420 (PE); ?, 3 Sep. 1952, F. Kun-Tsun 5662 (PE); ?, 16 Aug. 1952, W. Si-Tchou 16148 (PE); Anhui: ?, 12 Aug. 1935, T.N. Liou \& P.C. Tsoong 2577 (PE); ?, 14 Jul. 1975, ? 550 (PE); Mt. Huangshan, 22 Jul. 2010, B.H. Choi \& D.H. Lee 107301 107315 (IUI).

Leontopodium discolor Beauverd JAPAN. Hokkaido: Is. Rebun, Uennai, 13 Jul. 1983, T. Yamazaki 4658 (TI); Is. Rebun, Mt. Sankaku-yama, 14 Aug. 1984, K. Tatsumi \& S.Satoki 4119 (KYO). 